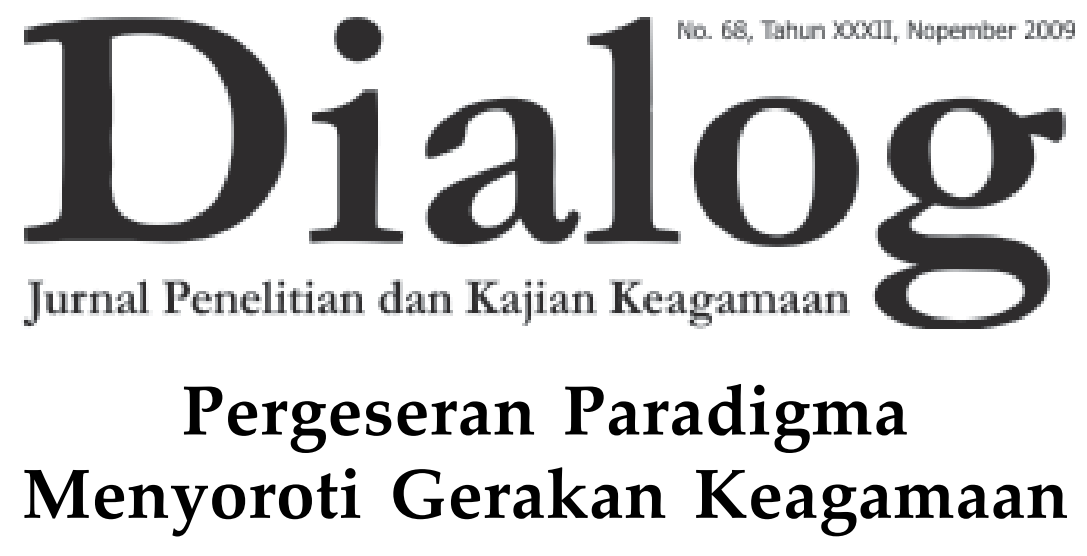




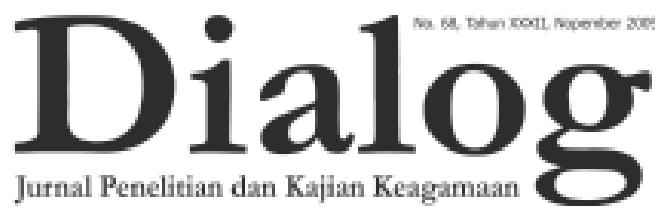

Pemi mpin Umum:

Prof. Dr. H. M. Atho Mudzhar, MA

Redaktur Ahli:

Prof. Dr. H. Nasaruddin Umar, MA

Prof. Dr. H. Komarudin Hidayat, MA

Pemimpin Redaksi / Penanggung J awab

Drs. H. Syamsuddin

Wakil Pemi mpin Redaksi

H. Fanani Suprianto, SH., MM

Sekretaris Redaksi

M. Rosyid Fauzi, S.Si.

Dewan Redaksı

Prof. Dr. H. Abdurrahman Mas'ud Drs. Amin Haedari

Prof. Dr. H. Maidir Harun

Drs. H. Mohammad Shohib, MA

Drs. H. Asmu'i, SH, MM

Chamdi Pamudji, SH., MM

Redaktur Eksekutif

M. Nasir, S.Th.I.

Redaktur Pelaksana

Moh. Rosyid Fauzi, S.Si

M. Nasir, S.Th.I

M. Adlin Sila, M.A

Abbas Jauhari, M.Ag

Administrasi

Drs. Dedy Curipno

Sutidjah

Desriyanti Nasution, S.IPI

Drs. H. Sahlani

Alamat Redaksi

Gedung Bayt Alquran Museum Istiqlal Komplek Taman Mini Indonesia Indah

Telp. (021) 87791444-87794982

Website:

www. balitbangdiklat.depag.go.id

Email:

info@depag.web.id

\section{Pergeseran Paradigma Menyoroti Gerakan Keagamaan}

Fenomena munculnya berbagai aliran keagamaan di Indonesia beberapa tahun terakhir menunjukan kecenderungan positif dalam kebebasan beragama. Namun sayangnya kebebasan menampilkan ekspresi keberagamaan tersebut kerapkali melampaui dari apa yang semestinya. Hal tersebut dapat kita lihat dengan munculnya gerakan keagamaan yang mengusung berbagai macam ajaran, ritual keagamaan yang aneh bahkan cenderung mengancam serta menodai kesucian aqidah, ibadah, ritual, dan pendirian mayoritas ummat yang sudah mapan. Sejak tahun 1989, setidaknya telah ada beberapa aliran keagamaan diberikan label haram oleh MUI (Majelis Ulama Indonesia), diantara aliran yang dianggap menyesatkan itu antara lain: Islam Jama'ah, Ahmadiyah, Ingkar Sunnah, Qur'an Suci, Sholat Dua Bahasa, Lia Eden dan al-Qiyadah al-Islamiyah.

Fenomena ini ditenggarai oleh sebagian pihak sebagai akibat dari kegagalan dakwah. Para da'i dianggap tidak mampu mentransformasikan nilainilai ajaran Islam secara kaffah 
(komprehensif) kepada ummat, dakwah selama ini sering bersifat eksklusif, menghakimi dan memprovokasi. Aktifitas dakwah hanya menampilkan Islam dari aspek langit atau 'ubudiyah (habluminallah) bukan aspek bumi dimana kehidupan sosial (habluminannas) bergulir, sehingga wajar berbagai permasalahan sosial yang dialami ummat tidak tersentuh. Fakta ini menyebabkan ummat mencari solusi lain atas permasalahan sosial yang mereka alami dengan cara "selingkuh" yaitu menganut sekte atau aliran baru dalam sebuah agama yang menawarkan solusi instan, namun cenderung "menyesatkan".

Para da'i, tokoh masyarakat, maupun para pemegang kebijakan ke depan harus mampu merubah paradigma yang selama ini salah dan telah mengkristal di kalangan ummat. Mereka diharapkan tidak berperan sebagai juru dakwah, juru vonis, juru putus, yang hanya menyampaikan pesan bil lisan di atas mimbar saja, tapi lebih dari itu, merek dituntut menjadi -meminjam istilah Clifford Geertz- cultural broker (makelar budaya), bahkan menjadi intermediary forces (kekuatan perantara) bagi permasalahan sosial ummat dalam istilah Hiroko Horikoshi.

Dalam kajian Jurnal Dialog Edisi ini mencoba mengulas tentang Pergeseran Paradigma Menyoroti Gerakan Keagamaan yang kerapkali menghadirkan tematema aktual di tengah-tengah masyarakat. Kajian Jurnal Dialog edisi ini diawali dengan tulisan Prof. Dr. H.M.
Atho Mudzhar tentang Instrumen Internasional dan Peraturan Perundangan Indonesia tentang Kebebasan dan Perlindungan Beragama. Dilanjutkan dengan tulisan Prof. Dr. Abdurrahman Mas'ud yang mengupas tentang Menyikapi Keberadaan Aliran Sempalan.

Sukris Sarmadi, Dosen STAIN Banjarmasin menghadirkan tulisan tentang Transformasi NU dalam Masyarakat Banjar Kini PerspektifPergeseran Gerakan Keagamaan di Kalimantan Selatan. Sedangkan M. Ulinnuha Khusnan, MA melalui tulisannya mencoba memotret Paradigma Keberagamaan Kaum Santri. Nurhasanah dosen UIN Jakarta menghadirkan tulisan tentang Politik Kebijakan Islamisasi Mahathir. Kajian jurnal dialog edisi ini kian lengkap dengan hadirnya tulisan Anwar Mujahidin, MA, tentang Science And Religion (Paradigma Al-Qur'an untuk IlmuIlmu Sosial Menurut Pemikiran Kuntowijoyo).

Di samping memuat artikel ilmiah, Jurnal Dialog edisi ini juga memuat laporan hasil penelitian oleh Ridwan Bustaman, tentang Analisis Wacana Kritis : Tayangan Kekerasan dalam Sinetron Bernuansa Keagamaan. Dan juga hasil penelitian saudara Basuki tentang Pesantren, Tasawufdan Hedonisme Kultural (Studi Kasus Aktualisasi Nilai-nilai Tasawuf dalam Hidup dan Kehidupan di Pondok Pesantren Modern Gontor). Serta hasil penelitian saudari Maryam tentang Interaksi Sosial Pelaku Konversi Agama Etnik Cina.

Kajian ini diakhiri dengan telaah 
buku yang mengulas buku karya Prof. Abdurrahman, 2009 yang berjudul Menebar Rahmat bagi Sekalian Alam. Semoga kajian yang dihadirkan Jurnal Dialog edisi ini memberikan manfaat yang berarti bagi para pembaca, khususnya dalam kajian Pergeseran Paradigma Menyoroti Gerakan Keagamaan. Selamat Membaca!

Redaksi

4 Dialog No. 68, Tahun XXXII, Nopember 2009 
TOPIK

M. Atho Mudzhar

Instrumen Internasional dan Peraturan Perundangan Indonesia tentang Kebebasan dan Perlindungan Beragama - -6

Abdurrahman Mas'ud

Menyikapi Keberadaan Aliran Sempalan --16

SUKRIS SARMADI

Transformasi NU dalam Masyarakat Banjar Kini Perspektif Pergeseran Gerakan Keagamaan di Kalimantan Selatan - 25

\section{Ulinnuha KhuSNAN}

Memotret Paradigma Keberagamaan Kaum Santri —41

\section{NuRHASANAH}

Politik Kebijakan Islamisasi Mahathir —65

\section{Anwar Mujahidin}

Science And Religion (Paradigma Al-Qur'An untuk Ilmu-Ilmu Sosial Menurut Pemikiran Kuntowijoyo) -78

\section{PENELITIAN}

\section{RidWAN Bustamam}

Analisis Wacana Kritis : Tayangan Kekerasan dalam Sinetron Bernuansa Keagamaan $\longrightarrow 97$

\section{BASUKI}

Pesantren, Tasawuf dan Hedonisme Kultural (Studi Kasus Aktualisasi Nilainilai Tasawuf dalam Hidup dan Kehidupan di Pondok Pesantren Modern Gontor) -112

MARYAM

Interaksi Sosial Pelaku Konversi Agama Etnik Cina --135

\section{BOOK REVIEW}

\section{Dewi $\mathbf{N}$}

Menebar Rahmat bagi Sekalian Alam —149 


\title{
Memotret Paradigma Keberagamaan Kaum Santri
}

\author{
OLEH : M. ULINNUHA KHUSNAN ${ }^{1}$
}

\begin{abstract}
Santri has been the first entity of Islamic education that contributed a lot to the independent proscees and the exixtance of this nation. In doing the significant role, santri groups have had variety of religious paradigm. Some had normative, fundamentalis, exclusive and conservative paradigm. But others had actualis, inclusive, contextualis, rasionalis and liberalis paradigm. This article potrayed the typology of santri's paradigm.
\end{abstract}

KeYWORDS:

paradigm, santri, tipology

\section{Pendahuluan}

Pesantren dikenal sebagai lembaga pendidikan Islam tertua di Indonesia. Bahkan umurnya jauh lebih tua bila dibandingkan dengan umur Indonesia sendiri. Pesantren juga dikenal sebagai lembaga yang mandiri dan berdikari. Di pesantren, santri sebagai entitas siswa, mendapatkan pengajaran nilai-nilai agama secara holistik. Beraneka ragam ilmu agama diajarkan di pesantren dalam format pembelajaran wetonan, ${ }^{2}$ sorogan, ${ }^{3}$ klasikal, hafalan, ataupun mudzâkarah.

${ }^{1}$ Dosen IIQ dan UIN Jakarta.

${ }^{2}$ Wetonan berasal dari bahasa Jawa, weton yang berarti wektu (waktu). Pengajaran model ini diberikan pada waktu-waktu tertentu, yaitu sebelum dan/atau sesudah melakukan shalat fardhu. Metode weton ini merupakan metode kuliah, dimana para santri mengikuti pelajaran dengan duduk di sekeliling kiai yang menerangkan pelajaran, santri menyimak kitab masing-masing dan membuat cacatan padanya (mensyarah-i). Di Jawa Barat, istilah wetonan ini disebut dengan bandongan atau layanan kolektif (collectife
Pola pendidikan dalam pesantren telah menjembatani kutub nilai-nilai

learning process). Secara lebih mendalam dapat dilihat dalam Departemen Agama RI, Pondok Pesantren dan Madrasah Diniyah, Pertumbuhan dan Perkembangannya, (Jakarta: Ditjen Kelembagaan Agama Islam Departemen Agama RI, 2003), h. 39

${ }^{3}$ Sorogan berasal dari bahasa Jawa, sorog yang berarti menyodorkan, sebab setiap santri menyodorkan kitabnya dihadapan kiai atau pembantunya (badal, asisten kiai). Sistem sorogan ini termasuk belajar secara individual (individu learning process), dimana seorang santri berhadapan dengan seorang guru, dan terjadi interaksi saling mengenal diantara keduanya. Sistem ini terbukti sangat efektif sebagai tahap pertama bagi seorang murid yang bercita-cita menjadi seorang yang alim. Sistem ini memungkinkan seorang guru mengawasi, menilai dan membimbing secara maksimal kemampuan seorang santri dalam menguasai materi pembelajaran. Sorogan merupakan kegiatan pembelajaran bagi para santri yang lebih menitikberatkan pada pengembangan kemampuan perorangan (individual), di bawah bimbingan seorang kiai atau ustadz. Lihat Departemen Agama RI, Pondok Pesantren dan Madrasah Diniyah....., h. 38; dan Hasbullah, Kapita Selekta Pendidikan Islam, (Jakarta: PT. Raja Grafindo Persada, 1999), h. 50-51 
Islam dengan perkembangan peradaban dunia. Hal ini sejalan dengan doktrin pesantren sendiri yang menganut paradigma jalan tengah antara 'aqli (rasionalis) dengan naqli (skripturalis). Rujukan dalam pesantren tidak hanya Al-Qur'an dan Hadis namun juga rasionalitas dan realitas empirik (melalui ijma' dan qiyas).

Harapannya, pesantren mampu menghasilkan lulusan yang dapat menjadi agent of change dan avant garde pembimbing pencerahan umat Islam di masa mendatang. Tentu saja, harapan itu harus sejalan dengan fungsi dan perannya sebagai kawah candradimuka kaum intelektual, yang dapat mengiringi pencerahan sejati umat manusia. ${ }^{4}$

Alhasil, akhirnya pesantren pun berhasil mencetak kader-kader unggul yang tidak saja qualified dalam bidang intelektualitas tapi juga terampil dan memiliki kelihaian dalam ranah diplomasi, politik dan budaya. Kendati tujuan akhir pesantren adalah untuk mencetak kader yang memiliki kualifikasi di bidang keagamaan (tafaqquh fi ad-din), namun output yang dihasilkan ternyata tidak lantas satu warna dan satu arah, tapi justru sangat bervariasi.

Di sana ada nama-nama seperti, Abdurrahman Wahid (Gus Dur) yang moderat, Nurcholis Madjid (Cak Nur) yang pluralis-rasionalis, dan Hidayat Nur Wahid yang revivalis. Tapi juga ada Abu Bakar Ba'asyir, Amrozi dkk yang fundamentalis dan Ulil Abshar Abdallah dkk yang liberalis. Keberagaman dan keragaman cara pandang kaum santri ini tentu saja tidak lepas dari

\footnotetext{
${ }^{4}$ Anjrah Lelono Broto, Fundamental dan Liberal dalam Islam, dimuat dalam blog www.anantapunya.com pada 5 September 2009
}

backgraund, sistem pengajaran dan paradigma keberagamaan yang dikembangkan di pesantren masingmasing.

Terkait dengan fenomena itulah, penulis tergelitik untuk meneliti cara berfikir output pesantren, kemudian membingkainya dalam sebuah frame paradigma keberagamaan kaum santri. Tulisan ini tidak berpretensi untuk memecah atau menyudutkan pesantren dan kaum santri, namun ini adalah usaha ilmiah-akademik untuk memetakan paradigma keberagamaan kaum santri sehingga memudahkan para pemerhati dan peneliti dalam proses identifikasi. Dalam kajian ini penulis berusaha untuk menghadirkan datadata primer dari berbagai sumber agar mendapatkan hasil yang maksimal.

Namun sebelum jauh masuk ke dalam ranah pemapingan, tulisan ini akan diawali dengan uraian singkat mengenai pengertian paradigma dan santri. Harapannya, agar terbangun sebuah pemahaman yang komprehensif dan epistema berfikir yang holistik tentang tema ini. Titik klimaksnya, tulisan ini akan diakhiri dengan pembahasan seputar tipologi paradigma keberagamaan kaum santri.

\section{Mengurai Makna Paradigma}

Tak pelak, paradigma merupakan hal yang sangat vital bagi aktifitas dan keberlangsungan hidup seseorang. Karena paradigma merupakan titik pijak dalam membangun konstruksi pemikiran dan cara memandang sebuah persoalan yang akan termanifestasikan dalam sikap dan prilaku sosial. Disamping itu, dengan paradigma ini pula seseorang akan menentukan dan memilih nilai-nilai yang universalabstrak menjadi khusus dan praksis- 
operasional yang akhirnya menjadi karakteristik dan gaya berpikirnya.

Kata paradigma muncul pada abad pertengahan di Inggris (tepatnya pada tahun 1483) yang secara etimologis merupakan kata serapan dari bahasa Latin, paradigma, yang berarti suatu model atau pola. Paradigma juga berasal dari bahasa Yunani, paradeigma (para+deiknunai) yang berarti untuk "membandingkan," "bersebelahan" (para) dan memperlihatkan (deik). ${ }^{5}$

Paradigma dalam disiplin intelektual adalah cara pandang seseorang terhadap diri dan lingkungannya yang akan mempengaruhinya dalam berpikir (kognitif), bersikap (afektif), dan bertingkah laku (konatif). ${ }^{6}$ Paradigma juga dapat berarti seperangkat asumsi, konsep, nilai, dan praktek yang diterapkan dalam memandang realitas dalam sebuah komunitas yang sama, khususnya dalam disiplin intelektual. ${ }^{7}$

Dalam khazanah ilmu sosial, paradigma adalah sebuah istilah keilmuan yang sangat penting sejak tahun 60-an. Istilah ini pertama-tama diperkenalkan oleh Thomas Kuhn, seorang ahli fisika dan sejarah ilmu pengetahuan asal Amerika Serikat, ketika ia berbicara tentang revolusi ilmu pengetahuan. Dalam bukunya, The Structure of Scientific Revolutions (1962), Thomas Kuhn menjelaskan bahwa istilah paradigma mengandung dua pengertian. Pertama, paradigma berarti keseluruhan konstelasi kepercayaan, nilai, teknik, dan sebagainya yang dimiliki bersama oleh anggota-anggota

\footnotetext{
${ }^{5}$ Etimologi Online: Paradigma

${ }^{6}$ Dani Vardiansyah, Filsafat Ilmu Komunikasi: Suatu Pengantar, (Jakarta: Indeks, 2008), h. 27

${ }^{7}$ Free Online Dictionary, Paradigm
}

masyarakat tertentu. Kedua, paradigma berarti sejenis unsur dalam konstelasi itu, pemecahan teka-teki yang konkrit, yang jika digunakan sebagai model atau contoh, dapat menggantikan kaidahkaidah eksplisit sebagai dasar pemecahan teki-teki ilmu pengetahuan yang normal yang masih tertinggal.

Sementara itu, G. Ritzer ${ }^{8}$ memberi pengertian paradigma sebagai pandangan fundamental tantang apa yang menjadi pokok persoalan dalam ilmu. Paradigma membantu apa yang harus dipelajari, pertanyaan yang harus dijawab, bagaimana semestinya pertanyaanpertanyaan itu diajukan dan aturanaturan apa yang harus diikuti dalam menafsirkan jawaban yang diperoleh. ${ }^{9}$ Paradigma ${ }^{10}$-sebagaimana ditulis Abdul Khaliq- ${ }^{11}$ adalah cara pandang dan cara berfikir terhadap respon yang dihadapi seseorang termasuk dalam fenomena sosial. Cara pandang tersebut tidak butuh terhadap tes ulang dan kontrol secara kuat terhadap cara kerja ide.

Karena itulah, paradigma tidak hanya berlaku pada hal-hal yang berkaitan dengan persoalan yang bersifat ilmiah, akan tetapi ia juga berlaku dalam wilayah yang masih samar-samar. ${ }^{12}$ Dengan kata lain,

\footnotetext{
${ }^{8}$ Lihat George Ritzer, Encyclopedia of Social Theory, (SAGE Publications, Inc, 2004), h. 68

9 Ach. Ma'ruf, Beredel Paradigma KritisTransformatif, dimuat dalam http:// pmiingalah.wordpress.com pada tanggal 7 Februari 2009

${ }^{10}$ Paradigma merupakan hasil tertinggi dari pencapaian intelektual yang dapat dijadikan patokan dasar ilmu pengetahuan biasa dan dapat menjadi landasan pijak aktivitas yang ilmiah (supertheory). Lihat Charles T. Tart, Transpersonal Psychologies, (New York: Happer \& Row, 1969), h. 17-18

${ }^{11}$ Abdul Kholiq, Paradigma Spiritualitas dalam Tradisi Sinoman, Penelitian Tradisi Sinoman dalam Masyarakat di Desa Bermi, Demak (tidak diterbitkan).

${ }^{12}$ Douglas A. Bernstein, Essentials of Psychology, (New York: Houghton Mifflin, 1999), h. 126
} 
paradigma dapat ditemukan dalam halhal yang dirumuskan secara ilmiah maupun dalam hal yang belum atau bahkan tidak punya landasan ilmiah yang jelas. Hal itu disebabkan oleh perbedaan tingkatan kesadaran yang dimiliki oleh seseorang ketika ia menilai sebuah fenomena.

Tampaknya konsep paradigma yang dikembangkan oleh Kuhn sebagaimana telah disebutkan di atasmemiliki cakupan makna yang sangat luas. Sebab setiap manusia, dalam pandangan Kuhn, memiliki paradigma, cara pandang tentang berbagai realitas yang berbeda. Kita memiki paradigma personal dan kultural mengenai sosial, ekonomi, politik, agama dan persoalan yang lain. Dan semua itu merupakan sistem kepercayan yang implisit dalam benak fikiran manusia di saat dia berfikir, mengerjakan dan menilai sesuatu. Secara historis, Kuhn juga telah menunjukkan bahwa terjadinya pertentangan paradigma (paradigm clashes) ditandai oleh rasa pertentangan dan perseteruan yang dalam dan juga sikap penolakan yang total terhadap lawan. Karena itu, perdebatan yang timbul dari berbagai ilmuan juga menunjukkan adanya keberadaan pertentangan yang bersifat emosinal. ${ }^{13}$

Lebih jauh, Kuhn melihat betapa manusia sangat dipengaruhi oleh apa yang ia sebut sebagai paradigma ini. Sedikit manusia yang dapat melepaskan diri dari kungkungan paradigma. Para ilmuan -manusia yang dinobatkan sebagai paling objektif dan rasionalpun tidak terlepas dari kungkungan paradigma yang berlaku. ${ }^{14}$ Bahkan

${ }^{13}$ John L. Eposito, The Oxford Encyclopedia of The Modern Islamic, (World, New York, 1995), III, h. 218

${ }^{14}$ Mohamad S. Iman, Paradigma Terorisme, dimuat di harian Republika pada 5 September 2003. perubahan paradigma dapat mengubah seseorang ke arah yang positif atau negatif, entah bersifat spontan atau bertahap, perubahan paradigma menggerakan dari satu cara melihat dunia ke cara yang lain. Dan perubahan paradigma tersebut menghasilkan perubahan yang kuat. Paradigma seseorang, benar atau salah, adalah sumber dari sikap dan prilakunya, dan pada puncaknya akan menjadi sumber dari segala hubungannya dengan orang lain.

Dari paparan di atas dapat ditarik pemahaman bahwa bentuk atau karakter tertentu dari paradigma atau cara pandang seseorang akan menentukan makna bagi realitas sosial. Bila pengertian paradigama di atas dihubungkan dengan kata keagamaan, maka yang dimaksud dengan paradigma keagamaan adalah, cara pandang seseorang tentang ajaran agama yang bersumber dari Tuhan. Paradigma keberagamaan ini akan menjadi keyakinan dan dasar dari seluruh aktivitas atau realita sosial suatu masyarakat. Dalam konteks inilah istilah paradigma keagamaan digunakan dan dibahas sebagai dasar bagi keterlibatan kaum santri dalam aspek pemikiran dan tradisi yang berkembang di masyarakat.

\section{Santri: "Sang Pengemban Amanat NABI"}

Santri. Siapa yang tidak mendengar kata ini. Hampir semua orang pasti pernah mendengarnya. Apalagi orangorang yang pernah hidup di lingkungan pesantren. Kata ini sungguh tidak asing lagi bagi mereka. Namun kemasyhuran kata ini ternyata masih menyisakan beribu pertanyaan yang sampai saat ini belum terpecahkan. 
Bahkan, para pakar budaya, bahasa dan sosiolog pun masih belum menemukan kata sepakat. Mereka masih berselisih pendapat tentang asal muasal dan makna kata yang terdiri dari enam huruf ini.

Pada awalnya, istilah "santri" lebih populer disematkan kepada para pelajar muslim yang menempuh pendidikan di pesantren. Di pesantren mereka secara khusus ditempa untuk menjadi ahli-ahli agama. Saat mereka berhasil menyelesaikan pendidikannya dan mendirikan kembali pesantren atau mengajarkannya kembali kepada masyarakat luas, sebutan untuk mereka berubah menjadi "kiai." Alhasil, istilah "santri" pada mulanya digunakan untuk membedakannya dengan "kiai" di suatu pesantren atau pusat pengajaran agama tradisional masyarakat Jawa.

Istilah "santri" kemudian oleh Clifford Geertz ${ }^{15}$ digunakan untuk menamai suatu kategori sosio-kultural dalam masyarakat muslim. Ia menyandingkannya dengan kategori

${ }^{15}$ Tidak dapat dipungkiri bahwa penyebutan "santri" sebagai suatu unit analisis sosial sangat dipengaruhi oleh publikasi penelitian Clifford Geertz tentang komunitas Islam di suatu kota yang ia sebut dengan "Mojokuto." Publikasi ini diterjemahkan ke dalam bahasa Indonesia dengan tajuk; Abangan, Santri, Priyayi dalam Masyarakat Jawa dari judul aslinya, The Religion of Java. Riset yang dilakukan selama enam tahun (1953-1959) di kota Pare-Pare Kediri ini memang tergolong paling awal dalam membuat klasifikasi "santri" sebagai suatu unit sosiokultural yang tumbuh di tengah masyarakat Jawa. Karena itu peneliti-peneliti setelah Geertz, banyak yang mengikuti jejaknya, terutama dalam hal kategorisasi "santri" sebagai suatu unit analisis tersendiri di tengah masyarakat muslim. Kategori ini digunakan, misalnya, dalam penelitian Zamakhsyari Dhofier, Tradisi Pesantren: Studi Tentang Pandangan Hidup Kyai, (Jakarta: LP3ES, 1994) dan Hiroko Horikoshi, Kyai dan Perubahan Sosial, (Jakarta: P3M, 1987) lain, yaitu "abangan" dan "priyayi". ${ }^{16}$ Menurut Geertz, ada dua perbedaan pokok antara kelompok santri dengan kelompok abangan; pertama berkenaan dengan doktrin pokok Islam (Al-Quran dan hadis) dan kedua berkenaan dengan persepsi tentang organisasi sosial (dalam konteks apa mereka menempatkan diri).

Terkait dengan hal pertama, bagi kelompok santri doktrin ajaran Islam adalah pegangan pokok yang harus mereka jalankan dalam kehidupan mereka sehari-hari. Sementara itu, kelompok abangan tidak terlalu mempedulikan doktrin agama. Perhatian mereka bukan pada doktrin melainkan pada adat kebiasaan yang berkembang di tengah-tengah masyarakat.

Oleh sebab itu, mereka akan sangat memperhatikan upacara-upacara seperti slametan untuk memperingati momenmomen khusus seperti kematian dan sebagainya tanpa mempedulikan apakah itu merupakan bagian dari -atau sekurang-kurangnya dibenarkan olehdoktrin ajaran Islam. Bagi kelompok santri, ritual apapun yang mereka kerjaan harus memiliki presedennya di

\footnotetext{
${ }^{16}$ Kategorisasi yang dilakukan Geertz ini menuai protes cukup kuat dari para sosiolog dan pengamat sosial. Sosiolog Indonesia seperti Harsya W. Bachtiar dan Parsudi Suparlan misalnya, sejak awal sudah mengkritik kategorisasi yang dilakukan Geertz ini, terutama terkait dengan dikotomisasi antara "abangan" dengan "priyayi" dan "santri" dengan "priyayi" berdasarkan kategori keagamaan. Bagi Suparlan, kategorisasi ini tidak tepat mengingat kelompok "priyayi" bukanlah kategori kelompok berdasarkan kriteria keagamaan. "Priyayi" adalah kategori sosial yang didasarkan pada garis keturunan. Menyandingkannya dengan "abangan" dan "santri" dalam satu garis kategoris tidak pada tempatnya. Lihat Parsudi Suparlan dalam "Kata Pengantar" untuk buku Clifford Geertz, Abangan, Santri, Priyayi Dalam Masyarakat Jawa, (Jakarta: Pustaka Jaya, 1983) h. vii-xiv
} 
dalam doktrin ajaran Islam. Bila tidak, mereka akan menganggapnya sebagai perbuatan menyimpang (bid'ah).

Mengenai persepsi tentang organisasi sosial, bagi kelompok abangan, yang menjadi pusat dalam kehidupan mereka pertama kali adalah keluarganya, kemudian meluas kepada masyarakat. Jadi, mereka memposisikan diri sebagai bagian dari "keluarga" yang mewariskan tradisi secara turuntemurun. Keberadaan masyarakat hanyalah penjumlahan dari keluargakeluarga. Oleh sebab itu, penghormatan mereka terhadap leluhur begitu tinggi.

Sementara itu, bagi kelompok santri, organisasi sosial yang mereka persepsikan bukan diasaskan pada ikatan "keluarga," melainkan pada ikatan "iman" yang membentuk suatu perkauman (Islam). Sebagai individu Muslim, ia merupakan bagian dari umat Islam di mana pun mereka berada. Ikatan ini lebih penting dari pada ikatan pada keluarga atau leluhur. Sentimen inilah yang melahirkan solidaritas khas atas dasar "iman". ${ }^{17}$

Secara singkat, apa yang dirumuskan Geertz ini dapat disimpulan bahwa kelompok "santri" adalah mereka yang menjalankan ajaran-ajaran dan doktrin-doktrin Islam secara lebih ketat dan taat. Sementara itu, kelompok "abangan" tidak terlalu mempedulikan masalah-masalah doktrinal di dalam Islam, sekalipun secara nominal mereka muslim, dan mereka lebih berorientasi pada tradisi.

Selain definisi dan ketegorisasi yang dilakukan Geertz, muncul pula definisidefinisi lain tentang terma "santri."

${ }^{17}$ Secara lebih komprehensif dapat dibaca dalam Clifford Geertz, Abangan, Santri, Priyayi ..., h. 172178
Misalnya adalah, kata "santri" disinyalir berasal dari bahasa jawa: cantrik yang berarti pelayan atau abdi. Jika asumsi ini benar, maka santri adalah seorang abdi yang siap mengabdikan dirinya untuk kepentingan agama.

Sementara menurut pengamatan beberapa pakar lainnya, kata "santri" berasal dari bahasa Inggris yaitu; sun (matahari) dan three (tiga), artinya; tiga matahari/cahaya. Berdasarkan difinisi kedua ini, kata santri mengandaikan sebuah tanda atau perlambang dari tiga ajaran pokok agama yang dibawa Nabi Muhammad Saw, yaitu; Iman, Islam dan Ihsan. ${ }^{18}$

Trisula ini merupakan inti dari ajaran yang dibawa Muhammad Saw. Seorang santri dituntut untuk memiliki dan mengamalkan tiga hal tersebut dalam hidup dan kehidupannya. Jika tiga ajaran pokok ini belum termanifesto dalam diri santri, maka ia belum dapat disebut dengan santri yang sesungguhnya.

Sementara dalam beberapa literatur yang dikarang oleh ulama Jawa, kata SANTRI disinyalir sebagai singkatan dari; Sanggup Nerusno Tuntunan Rasul Ilahi. Artinya, sanggup mengemban amanat yang diajarkan oleh Rasululullah Saw. Berdasarkan definisi ini, santri sebenarnya adalah kepanjangan tangan dari para ulama, karena mereka adalah orang yang mewarisi ilmu para ulama.

${ }^{18}$ Terkait dengan Iman, Islam dan Ihsan ini, Abu al-Husain Muslim bin al-Hajjaj bin Muslim bin Kausyaz al-Qusyairi an-Naisaburi $(202-261 \mathrm{H})$ dalam kitab Shahih-nya melansir sebuah hadits yang sangat popular dari Umar bin Khattab. Dalam hadits itu, konsepsi Iman, Islam dan Ihsan diterangkan secara jelas oleh Rasulullah Saw. Secara lebih lengkap, hadits tersebut dapat dibaca dalam Imam Muslim, Shahih Muslim, (Bairut: Dâr Shadir, t.t.), h. 175 
Dalam sebuah hadits disebutkan bahwa; "Ulama adalah pewaris para Nabi." Jika ulama berprediket sebagai pewaris para nabi, dan santri sebagai pewaris para ulama, maka secara tidak langsung santri juga pewaris para Nabi. Karena alasan inilah, maka tugas meneruskan risalah atau ajaran yang dibawa Rasullullah Saw merupakan hal yang niscaya bagi seorang santri.

Abdul Munir Mulkhan dalam buku Runtuhnya Mitos Politik Santri: Strategi Kebudayaan dalam Dakwah Islam ${ }^{19}$ menjelaskan bahwa kata "santri" dalam khazanah kehidupan bangsa dan masyarakat Islam di Indonesia memiliki dua makna. Pertama, menunjuk ke sekelompok peserta sebuah pendidikan pesantren atau pondok. Kedua, menunjuk ke akar budaya sekelompok pemeluk Islam sebagaimana juga dimaknai oleh Clifford Geertz.

Sekilas, berbagai definisi di atas terlihat saling kontradiksi. Tapi jika diteliti secara mendalam, sesungguhnya semuanya memiliki kemiripan -untuk tidak mengatakan kesamaan- esensi. Tiga definisi tersebut memiliki titik temu yang sama, setidaknya dalam dua hal; pertama, tugas seorang santri yaitu; sebagai pengemban amanat. Kedua, isi amanat yang harus dikerjakannya yakni; ajaran Islam yang dibawa Rasulullah Saw.

Dari uraian di atas dapat ditarik konklusi bahwa santri adalah seorang abdi yang mendapat amanat atau tugas untuk meneruskan ajaran/risalah yang dibawa Rasulullah Saw. Ajaran tersebut terangkum dalam tiga aspek pokok yaitu; Iman, Islam dan Ihsan. Dalam

${ }^{19}$ Abdul Munir Mulkhan, Runtuhnya Mitos Politik Santri: Strategi Kebudayaan dalam Dakwah Islam, (Yogyakarta: Sipress, 2004), h. 1 proses penyebaran serta pengejawantahan tiga ajaran tersebut dibutuhkan kelihaian dan kemampuan yang maksimal dari seorang santri. Tanpa itu, ajaran yang agung tersebut akan mengalami "titik buntu" dalam proses manifestasi dan pengembangannya.

\section{Tipologi Paradigma \\ KeberagamaAn Santri}

Pada mulanya santri memiliki cara pandang yang sama (atau setidaktidaknya seragam) tentang ajaran agama Islam. Agama Islam dipahami sebagai sebuah ajaran adiluhung yang datang dari Tuhan untuk mengatur kemaslahatan hidup manusia. Dalam rangka mewujudkan itu, maka Islam datang dengan tiga pilar doktrin dasar yaitu akidah, syari'ah dan akhlak. ${ }^{20}$ Kemudian agama ini lahir dalam bentukbentuk yang plural sesuai dengan corak sosio-ekonomi tiap-tiap masyarakat pada masanya. ${ }^{21}$ Dalam perkembangan selanjutnya, ajaran agama ini kemudian mengalami perubahan bentuk aplikasi pemaknaan di kalangan umat Islam, khususnya di kalangan santri. Dari perbedaan pemaknaan ini kemudian mewujud menjadi sebuah paradigma keagamaan. Sejalan dengan perubahan pemaknaan dan paradigma tersebut, dapat dikemukakan bahwa sampai saat ini, ada beberapa paradigma fundamental yang berkembang di kalangan santri, antara lain:

${ }^{20}$ Lihat Direktorat Pembinaan Perguruan Tinggi Agama Islam Dirjen Bagais Depag RI, Buku Teks Pendidikan Agama Islam Pada Perguruan Tinggi Umum, (Jakarta: PT. Bulan Bintang, t.t.), Cet. I, h. 101-175

${ }^{21}$ Lihat Harun Nasution, Islam Ditinjau Dari Berbagai Aspek Jilid I, (Jakarta: UI Press, 1985), Cet. V, h. 11-14 


\section{Normatif}

Secara etimologis, normatif berasal dari bahasa Inggris norm yang berarti norma, ajaran, acuan, ketentuan tentang masalah yang baik dan buruk, yang boleh dilakukan dan yang tidak boleh dilakukan. ${ }^{22}$ Dalam konteks ini, yang dimaksud dengan norma adalah akhlak yaitu perbuatan yang muncul dengan mudah dari kesadaran jiwa yang bersih dan dilakukan atas kemauan sendiri, bukan pura-pura dan bukan pula paksaan. Karena akhlak adalah inti dari ajaran agama ${ }^{23}$ (Islam), maka norma sering diartikan pula dengan agama.

Berdasarkan penjelasan di atas, maka paradigma normatif adalah paham yang meyakini bahwa Islam adalah wahyu yang berasal dari Tuhan, wajib diyakini, diterima sebagai kebenaran mutlak yang tidak boleh diganggu gugat. Dalam konteks ini Amin Abdullah mengatakan, Islam normatif adalah paham yang berangkat dari teks yang sudah tertulis dalam kitab suci masing-masing agama, sampai batasbatas tertentu, adalah bercorak literalis, tekstualis atau skripturalis. ${ }^{24}$ Paradigma keagamaan normatif lebih menekankan pada aspek batiniah-eksoterik serta makna terdalam dan moralitas yang dikandung oleh ajaran agama. Paradigma keagamaan ini cenderung mengabsahkan teks yang sudah tertulis, tanpa berusaha memahami lebih dahulu apa sesungguhnya yang melatarbe-

${ }^{22}$ John M. Echols dan Hasan Shadily, Kamus Bahasa Inggris-Indonesia, (Jakarta: PT. Gramedia, 1979), Cet. VII, h. 396

${ }^{23}$ Lihat Fazlur Rahman, Islam (terj.) Senoaji Saleh, (Jakarta: Bina Aksara, 1987), h. 49

${ }^{24}$ M. Amin Abdullah, Studi Agama Normativitas atau Historisitas?, (Yogyakarta: Pustaka Pelajar, 1996), h. vi lakangi teks keagamaan tersebut. ${ }^{25}$ Dengan demikian, paradigma keberagamaan normatif dibangun, diramu, dibakukan dan ditelaah lewat pendekatan doktrinal teologis.

Kaum santri yang berparadigma normatif memiliki ciri-ciri antara lain, pertama, kecenderungan untuk mengutamakan loyalitas kepada kelompoknya sendiri sangat kuat; kedua, adanya keterlibatan pribadi (involvement) dan penghayatan yang begitu kental dan pekat kepada ajaran-ajaran teologi yang diyakini kebenarannya; ketiga, mengungkapkan perasaan dan pemikiran dengan menggunakan bahasa pelaku. Menyatunya ketiga ciri tersebut dalam diri seorang santri atau kelompok santri memberi andil cukup besar bagi terciptanya komunitas teologi yang cenderung bersifat eksklusif, emosional, dan kaku. Ketiga ciri ini juga mendorong para penganutnya untuk mendahulukan truth claim dari pada dialog yang jujur dan argumentatif.

Secara teologis, para santri penganut paradigma normatif beranggapan bahwa manusia itu terbelenggu dalam dogma dan keyakinan yang dianutnya, sehingga dirinya terkungkung dalam kerangka kehidupan keagamaan yang statis.

\footnotetext{
${ }_{25}$ Paradigma keberagamaan ini kurang mendalami sebab-sebab diturunkannya wahyu (asbâb an-nuzûl), baik yang bersifat psikologis maupun psikologis. Karena itu, para sosiolog acapkali menyandingkan paradigm ini dengan paradigm historis yang memahami keberagmaan manusia dari berbagai sudut pandang keilmuan social-keagamaan yang bersifat multi disipliner, baik lewat historis, filosofis, psikologis, sosiologis, cultural maupun antropologis. Lihat dalam M. Amin Abdullah, Studi Agama..., h. vi; dan Abuddin Nata, Peta Keragaman Pemikiran Islam di Indonesia, (Jakarta: PT. Raja Grafindo Persada, 2001), h. 30
} 
Manusia benar-benar terkungkung dalam terali skeptisisme dan kepasrahan yang ekstrim. Ini disebabkan oleh doktrin teologis yang dikembangkan, bahwa manusia adalah "objek" yang bersifat depend terhadap suatu kekuatan di luar dirinya. ${ }^{26}$

Secara sosiologis, paradigma ini tidak menghendaki adanya dialektika secara bebas dan terbuka dengan peradaban dan kebudayaan lain yang berada di luar dirinya, demikian pula terhadap nilai kebenaran. Nilai kebenaran dianggap berjalan secara linier dan amat normatif-formalistik, steril dari berbagai macam dialektika. Karena itu, kaum santri yang berparadigma ini lebih mengedepankan klaim kebenaran ketika dihadapkan pada fakta atau realitas yang memuat nilai asing atau berbeda dengannya.

Secara politis, paradigma normatif sewaktu-waktu bisa muncul menjadi ideologi politik yang tiranik. Agama kemudian dijadikan sebagai legitimasi kekuasaan dan kebijakan politik. Tuhan seakan-akan berada di balik semua itu sebagai sebuah kekuatan yang mengabsahkan. Penganut paradigma ini amat lemah ketika berhadapan dengan tuntutan rasa kemanusiaan seperti kemerdekaan, keadilan, egalitarian, demokrasi dan nilai-nilai kemanusiaan lainnya, termasuk juga

${ }^{26}$ Syamsul Arifin, dkk., Spiritualisasi Islam dan Peradaban Masa Depan, (Yogyakarta: SIPRESS, 1996), h. 22. Paradigma seperti ini tentu menjadikan kesadaran manusia bergerak linier hanya dalam dimensi mistis, dan mereduksi kesadaran kosmis manusia yang pada dasarnya ia berada dan menjadi bagian dari kosmis itu. Karena itu, sistem pengetahuan dan sosialnya dibangun atas dasar paradigma yang teosentris. Titik klimaks paradigma ini adalah penyangkalan peran kosmis manusia sebagai khalifah dan sebagai subjek yang menentukan nasibnya sendiri. terhadap perkembangan ilmu pengetahuan. ${ }^{27}$

Dari pemaparan di atas, terlihat bahwa paradigma normatif adalah paham yang bertolak dari kekuasaan yang memusat pada Tuhan (teocentris). Segala yang berasal dari Tuhan mutlak adanya, dan harus dijadikan dasar dan acuan dalam memutuskan berbagai aspek kehidupan baik sosial, politik, kebudayaan dan lain sebagainya. Dengan paradigma yang demikian, kebebasan manusia menjadi terkungkung, menolak berbagai kreasi dan pendapat yang berasal dari luar, dan cenderung dogmatik dan eksklusif.

Kendati demikian harus diakui bahwa paradigma normatif dapat mendorong para penganutnya (santri) untuk taat dan patuh kepada Tuhan dengan segenap daya dan kemampuan yang dimilikinya. Mereka mau dan rela mengorbankan apa saja yang dimilikinya jika yang memrintahkan dirinya adalah Tuhan. Mereka terkadang berbuat yang secara lahiriah menyakitkan dan menyengsarakan diri, namun secara batiniah hal itu sangat menyenangkan karena perbuatan tersebut diperintahkan Tuhan, seperti jihad, berpuasa, bahkan bunuh diri. Sikap yang demikian selanjutnya membawa para santri kepada apa yang disebut dengan kesalehan individual dan melupakan kesalehan sosial.

\section{Kontekstual}

Secara etimologis, kontekstual berasal dari bahasa Inggris, context, yang berhubungan dengan kata-kata, suasana dan keadaan. Lalu menjadi kata contextual yang berhubungan dengan

\footnotetext{
${ }^{27}$ Nata, Peta Keragaman..., h. 32
} 
konteks, dilihat dalam hubungan dalam kalimat. ${ }^{28}$ Dalam pengertian lain, kontekstual berarti keadaan atau situasi dimana suatu kalimat atau perkataan itu dikatakan. Indikator di mana kata-kata itu diucapkan ikut mempengaruhi. Dengan pengertian tersebut dapat diketahui bahwa Islam kontekstual adalah Islam yang dalam penjabarannya senantiasa memperhatikan situasi dan kondisi di mana Islam itu dikembangkan.

Santri berparadigma kontekstual akan selalu berusaha menjabarkan dan mengamalkan ajaran Islam sesuai dengan konteks di mana mereka hidup. Hal ini didasarkan kepada kenyataan bahwa Islam adalah agama universal yang selalu cocok dengan zaman dan tempat (shâlih li kulli makân wa zamân). Terjadinya perbedaan corak, isi dan misi kandungan Al-Qur'an yang diturunkan di Mekah dan Madinah ${ }^{29}$ misalnya, adalah bukti bahwa ajaran Islam selalu sejalan dengan konteks di mana ia diturunkan.

Paradigama kontekstual ini muncul sebagai reaksi terhadap berbagai paham tentang Islam yang belakangan ini dikembangkan oleh sebagain para ahli, tanpa melihat permasalahan yang sedang dihadapi masyarakat. Pemahaman Islam yang dikembangkan di negara lain misalnya ingin dikembangkan di Indonesia, tanpa melihat apakah paham tersebut sesuai

\footnotetext{
${ }^{28}$ Echols, Kamus Bahasa Inggris..., h. 143

${ }^{29}$ Pembahasan seputar perbedaan ayat-ayat yang diturunkan di Mekah dan sekitarnya (Makkiyah) dengan ayat-ayat yang diturunkan di Madinah dan sekitarnya (Madaniyah) secara lebih mendalam dapat dibaca dalam Mannâ' al-Qhatthan, Mabahits fì 'Ulûm al-Qur'ân, (Mansyurat al-'Ashr al-Hadits, t.t.), h. 6162; Lihat pula Subhi Shalih, Membahasa Ilmu-Ilmu Al-Qur'an (terj.), (Jakarta: Pustaka Firdaus, 1991), h. 208-209
}

atau tidak dengan konteks keIndonesia-an. Pada titik inilah, pemahaman tentang asbâb nuzûl ayat AlQur'an sangat diperlukan. ${ }^{30}$ Para pengikut paradigma kontekstual akan selalu melihat ayat tidak saja secara literalnya, tetapi berusaha melompati makna-makna literal itu menuju maknamakna kontekstual.

Dengan memahami konteks sosial dalam memahami ajaran Islam, akan menghindarkan seseorang dari pemahaman yang salah tentang ajaran Islam. Memahami konteks sosial dalam mengajarkan ajaran Islam akan menyebabkan dipilihnya metode dan pendekatan yang tepat dalam menyampaikannya. Pemahaman kontekstual ini sering dilakukan Nabi Saw. Karena tingkat sosial dan pemahaman sasaran dakwah berbeda, maka Rasulullah Saw menempuh cara, metode dan pendekatan yang berbeda pula. Metode penyampain ajaran kepada orang kaya misalnya, tentu akan berbeda dengan penyampaian kepada orang miskin. Kontekstualisasi inilah yang dyakini oleh para penganutnya sebagai sebuah usaha untuk membumikan ajaran Islam yang ideal ke dalam berbagai ranah dan lintas waktu. Dengan ini pula adagium al-Islâm shâlih li kulli zamân wa makân akan terwujud.

\section{Fundamentalis}

Secara harfiah, kata fundamentalis berasal dari bahasa Inggris yang berarti pokok, asas, fundamentil. ${ }^{31}$ Sedangkan

${ }^{30}$ Asbab an-nuzul adalah salah satu alat untuk memahami ayat Al-Qur'an, karena itu Al-Wahidi mengatakan tidak mungkin mengetahi tafsir ayat AlQur'an tanpa berpegang pada kisah dan penjelasan turunnya ayat tersebut. Lihat Al-Wahidi, Asbâb anNuzûl, (Kairo: Dâr at-Tirats al-'Arabi, t.t.), h. 45

${ }^{31}$ Echols, Kamus Bahasa Inggris..., h. 260 
kata pokok atau asas dalam bahasa Indonesia berarti dasar, alas, pondasi, atau sesuatu yang menjadi pokok dasar atau tumpuan berfikir (berpendapat) dan sebagainya serta cita-cita yang menjadi dasar. ${ }^{32}$

Dengan demikian, paradigma keberagamaan fundamentalis adalah pemahaman keagamaan yang bertumpu kepada hal-hal yang asasi. Dengan kata lain, secara harfiah santri yang percaya kepada Rukun Iman yang enam dan menjalankan Rukun Islam yang lima, dapat disebut sebagai santri yang berparadigma fundamentalis, karena apa yang disebut ajaran fundamental dalam Islam adalah ajaran yang tercakup dalam Rukun Iman dan Rukun Islam itu. $^{33}$

Kaum santri yang berparadigma fundamentalis cenderung menonjolkan sifat gerakan yang agresif dan konservatif. Pada perkembangan selanjutnya, fundamentalisme di kalangan santri menimbulkan suatu ciri tertentu misalnya, ekstrimisme, fanatisme, atau bahkan terorisme yang mewujudkan atau mempertahankan keyakinan keagamaan. Santri fundamentalis cenderung tidak rasional, tidak moderat dan bila perlu melakukan tindakan kekerasan. ${ }^{34}$

Ciri-ciri lain yang melekat pada santri fundamentalis adalah sikap dan pandangan mereka yang radikal, militan, berfikir sempit, bersemangat secara berlebihan, dan ingin mencapai

${ }^{3}$ W.J.S Poerwadarminta, Kamus Umum Bahasa Indonesia, (Jakarta: Balai Pustaka, 1991), Cet. XII, h. 61

${ }^{33}$ Nata, Peta Keragaman..., h. 10-11

${ }^{34}$ Dawam Raharjo, "Fundamentalisme" dalam Muhammad Wahyuni Nafis (ed.), Rekonstruksi dan Renungan Religius Islam, (Jakarta: Paramadina, 1996), h. 86 tujuan dengan cara-cara kekerasan. Karena itu, tidak heran bila kemudian sebagian besar intelektual muslim melihat fundamentalisme sebagai istilah yang tidak menguntungkan dan menimbulkan kesalah pahaman. Pandangan seperti ini juga terdapat pada para orientalis dan sarjana Barat yang memahami Islam, seperti yang pernah dilakukan oleh van Bruinessen. ${ }^{35}$

Kaum santri yang berparadigma fundamentalis biasanya menafsirkan teks-teks keagamaan secara rigid dan literalis. Santri fundamentalis menganggap bahwa modernisme yang cenderung menafsirkan teks-teks secara elastis dan fleksibel dengan alibi untuk menyesuaikan dengan tuntutan zaman modern, akhirnya membawa agama pada titik marginal. Santri fundamentalis menuduh kaum modernis sebagai pihak yang bertanggung jawab terhadap terjadinya proses skularisme secara besar-besaran, di mana peranan agama akhirnya semakin terkesampingkan dan digantikan oleh peranan sains modern. ${ }^{36}$

Menurut pengamatan Kuntowijoyo, penganut paradigma fundamentalis merupakan gerakan antiindustri, suatu hal yang tidak disadari bahkan oleh pengikut faham ini sendiri. Karena bagi mereka, industrialisme telah melahirkan dampak negatif: (1) dominasi masa lalu oleh masa kini; (2) dominasi industri atas alam; dan (3) dominasi bangsa atas bangsa. Hal ini berbeda dengan pengamatan M. 'Âbid al-Jâbirî. Menurutnya, 'fundamentalis'

\footnotetext{
${ }^{35}$ Nata, Peta Keragaman....., h. 18

36 Yusril Ihza Mahendra, "Fundamentalisme, Faktor dan Masa Depannya," dalam Muhammad Wahyuni Nafis (ed.), Rekonstruksi dan Renungan Religius Islam, (Jakarta: Paramadina, 1996), h. 98
} 
pada awalnya dicetuskan sebagai signifier bagi gerakan Salafiyyah Jamaluddin al-Afghânî. Istilah ini, dicetuskan karena bahasa Eropa tak punya istilah padanan yang tepat untuk menterjemahkan istilah Salafiyyah. Hingga Anwar Abdul Malik pun memilih istilah itu sebagai representasi dari istilah Salafiyyah al-Afghânî, dalam bukunya Mukhtarât min Al-Adab Al-Arabi Al-Mu'âshir (1965: berbahasa Prancis), dengan tujuan memudahkan pemahaman dunia tentangnya dengan istilah yang sudah cukup akrab; fundamentalisme. ${ }^{37}$

Santri fundamentalis memiliki ciriciri sebagai berikut: pertama, mereka ingin kembali ke masa Rasul Saw. Kedua, mereka ingin kembali ke alam (back to nature). Sebagai contoh, mereka menolak wewangian buatan pabrik dan cenderung memakai bahan alamiah seperti siwak, minyak wangi tanpa alkohol dan sejenisnya. Ketiga, fundamentalisme mempunyai implikasi politik. Ini barangkali yang menyebabkan negara-negara industrial mencap fundamentalisme sebagai terorisme. $^{38}$

Secara subtantif, santri fundamentalis tidak dapat dikatakan keluar dari ajaran Islam. Justru sebaliknya, mereka adalah kelompok yang sangat berpegang teguh pada ajaran Islam dan ingin mempertahan-

${ }^{37}$ M.' Âbid al-Jâbirî, Dharûrah al-Bahts 'an Niqath al-Iltiqâ li Muwâjahah al-Mashîr al-Musytarak, dalam Hassan Hanafi \& M. 'Âbid Al-Jâbirî, Hiwâr al-Masyriq wa al-Maghrib, (Bairut: Muassasah al-Arabiyyah, 1990), h. 32-34

${ }^{38}$ Negara-negara seperti Iran, Libia, Al-Jazair, Somalia, Sudan, dan Saudi Arabia adalah negaranegara yang dianggap oleh negara-negara industri Barat (terutama Amerika) sebagai sarang fundamentalis dan teroris. Diskursus ini dapat dibaca secara mendalam dalam Kuntowijoyo, Identitas Politik Umat Islam, (Bandung: Mizan, 1997), h. 49 kannya dengan sekuat tenaga agar ajaran Islam tetap langgeng dan dapat dilaksanakan oleh seluruh umat manusia. Kendati demikian, ada beberapa hal yang menjadi catatan dari santri penganut fundamentalisme.

Pertama, dari sisi keyakinan keagamaan, mereka cenderung bersikap rigid dan literalis. Santri fundamentalis sangat menekankan simbol-simbol keagamaan daripada subtansinya. Mereka menganggap bahwa doktrin agama telah mengatur segala-galanya. Agama dinilai sebagai sebuah sistem yang lengkap dan mencakup pula berbagai sub-sistem di dalamnya. Kedua, mereka cenderung bersikap dan berpandangan eksklusif, yaitu pandangan yang bertolak dari keyakinan bahwa pandangan dan keyakinan merekalah yang paling benar. Sedangkan sikap dan pandangan orang lain yang tidak sejalan dengan mereka dianggap salah dan karenanya harus dikutuk dan ditolak. Konsekwensi dari sikap dan pandangan ini, mereka cenderung tertutup dan tidak mau menerima pandangan dan sikap orang lain yang berbeda, tidak terbuka dan tidak ada jalan baginya untuk berdialog. Ketiga, dari sisi budaya dan sosial, mereka terlihat sangat kaku dalam menyikapi produk budaya modern, kendatipun pada tataran yang sifatnya kultural, seperti pakaian, alat-alat kebersihan dan sebagainya. Sehingga kehidupan mereka terkesan kolot, kuno bahkan cenderung nyeleneh. Keempat, dari sisi bentuk dan sifat gerakannya, mereka cenderung memaksakan kehendak dengan menggunakan berbagai cara termasuk cara-cara kekerasan seperti propaganda, hasutan, teror, bahkan pembunuhan. Karenanya mereka acapkali dituding sebagai 
kelompok gerakan radikal dan fanantik. Kelima, dari sisi kelompok, mereka tampak memiliki ikatan solidaritas yang cukup solid, kokoh, militan dan rela menerima risiko dari sebuah perjuangan.

\section{EKSKLUSIF}

Secara bahasa, eksklusif berasal dari bahasa Inggris, exlusive, yang berarti sendirian, dengan tidak disertai yang lain, terpisah dari yang lain, berdiri sendiri, semata-mata dan tak ada sangkut pautnya dengan yang lain. ${ }^{39}$ Sementara dalam Kamus Bahasa Indonesia eksklusif diartikan dengan sifat mengasingkan diri, tidak bersedia menerima atau mengizinkan masuknya anggota baru, dan tidak termasuk. ${ }^{40}$ Secara umum, eksklusif adalah sikap yang memandang bahwa keyakinan, pandangan, pikiran dan prinsip diri sendirilah yang paling benar, sementara keyakinan, pandangan, pikiran, dan prinsip yang dianut orang lain salah, sesat dan harus dijauhi. Akibat dari sikap itu, penganut paradigma ekslusivisme cenderung tidak mau menerima saran, masukan, dan pemikiran yang berasal dari luar. Dengan demikian, dialog yang didasarkan pada kemitraan dan kesederajatan juga tidak terjadi. ${ }^{41}$

Secara sederhana, eksklusivisme dapat dibagi menjadi dua hal; pertama, eksklusivisme internal. Yaitu sikap, pandangan dan persepsi yang terdapat di dalam Islam sendiri. Diketahui bahwa dalam Islam terdapat berbagai aliran dan madzhab, baik dalam bidang teologis, fikih maupun tasawuf. Beragamnya

\footnotetext{
${ }^{39}$ Echols, Kamus Bahasa Inggris..., h. 222

${ }^{40}$ Tim Penulis, Kamus Bahasa Indonesia, (Pusat Bahasa Depdikbud RI, 2008), h. 379

${ }^{41}$ Nata, Peta Keberagaman..., h. 42
}

aliran dan madzhab ini sedikit banyak telah mewariskan sikap eksklusivisme pada santri, sebab mereka menganggap madzhab yang dianutnyalah yang paling benar, sedangkan madzhab lain salah atau tersesat. Kedua, eksklusivisme eksternal. Yaitu sikap eksklusif terhadap agama lain. Agama Islam diyakini sebagai yang paling benar, sedangkan agama orang lain sebagai sesat, kafir dan tidak akan diterima Tuhan.

Munculnya paradigma eksklusivisme di kalangan santri disebabkan karena beberapa hal, antara lain; pertama, faktor doktrin agama. Secara aksiomatik diakui bahwa pada awalnya agama berada pada titik kemurnian dan otentisitasnya. Namun dalam perjalannya, ajaran agama mengalamai pergeseran karena ulah tangan manusia sehingga ia berubah dari titik otentitas dan orisinalitasnya..$^{42}$ Pergeseran ajaran agama ini membuat sebagian santri bersikap hati-hati terhadap kemungkinan tercampurnya ajaran Islam dengan ajaran-ajaran lain. Sikap kehati-hatian ini selanjutnya berubah menjadi sikap eksklusif, karena mereka takut akidahnya tercampur oleh akidah agama lain yang mengandung unsur kemusyrikan.

Kedua, pemahaman tentang kesempurnaan ajaran Islam. ${ }^{43}$

\footnotetext{
${ }^{42}$ Contohnya adalah apa yang telah terjadi pada agama-agama sebelum Islam seperti Yahudi dan Nasrani. Pada awalnya penganut agama ini mengimani bahwa Tuhan yang patut disembah hanyalah Allah Swt. Namun pada perkembangan sejarahnya, para penganut Yahudi meyakini bahwa Uzair adalah anak Allah, dan penganut nasrani meyakini Tuhan dalam konsep trinitas (Tuhan Bapak, Tuhan Anak dan Roh Kudus). Lihat QS. Al-Mâ'idah [5]: 5-17, 72, dan 73; juga QS. Al-An'âm [6]: 164

${ }^{43}$ Kesempurnaan ajaran Islam ini dapat dilihat misalnya dalam QS. Al-Isrâ' [17]: 23-37 dan QS. ArRûm [30]: 30
} 
Berdasarkan petunjuk surat Al-Mâ'idah ayat 3 bahwa ajaran Islam yang dibawa Nabi Saw adalah ajaran sempurna dan paripurna. Islam datang untuk menyempurnakan agama-agama yang dibawa para rasul sebelumnya. Ibarat sebuah bangunan, agama yang dibawa nabi-nabi terdahulu ternyata masih ada celahnya, sehingga kedatangan Nabi Saw dengan agama Islam adalah dalam rangka untuk menyempurnakan konstruksi tersebut sehingga menjadi sebuah bangunan yang utuh dan kokoh. Dengan melihat ajaran Islam yang sempurna dan sesuai dengan fitrah manusia, maka timbul anggapan atau sikap tidak merasa perlu untuk belajar atau mengetahui agama lain. Justru sebaliknya, penganut agama-agama lainlah yang harus masuk ke dalam agama Islam.

Ketiga, faktor wawasan yang sempit. Sempitnya wawasan keagamaan yang dimiliki seorang santri dapat menjadi penyebab timbulnya sikap eksklusif. Sempitnya wawasan bisanya diakibatkan karena sistem atau bacaan yang kurang mendalam terhadap khazanah Islam. Karena buku yang dibaca hanya bersifat satu arah, maka kemungkinan untuk melihat aliran lain semakin sulit. Karena madzhab atau aliran yang diketahui hanyalah satu warna, maka kemungkinan untuk mengetahui pendapat orang lain semakin tertutup. Dalam titik inilah sikap eksklusivitas itu hadir.

Keempat, faktor sejarah. Karena pengalaman sejarah yang buruk, terkadang mengakibatkan seseorang bersikap eksklusif. Sebagai contoh, terusirnya umat Islam dari Spanyol, setelah mereka berkuasa selama tahun 711-1292 M. ternyata menyisakan duka cukup mendalam. ${ }^{44}$ Perang salib yang berlangsung selama tiga periode dari tahun 1095-1292 M., atau kurang lebih dalam kurung waktu tiga abad, ${ }^{45}$ ternyata menyisakan rasa trauma yang luar bisa bagi umat, sehingga tidak sedikit yang bersikap eksklusif karena kejadian menyedihkan itu. Konflik yang terjadi antara umat Islam dan Hindu pada zaman Kerajaan Mughal (14821617 M) juga menyisakan sikap eksklusivitas yang luar biasa. Peristiwa sejarah yang traumatik itu ternyata sedikit banyak membawa dampak kepada sebagian kaum santri untuk bersikap eksklusif.

\section{INKLUSIF}

Kata inklusif berasal dari bahasa Inggris, inclusive, yang berarti sampai dengan dan termasuk. ${ }^{46}$ Paradigma inklusif selanjutnya digunakan untuk menunjukkan paham keberagamaan yang didasarkan pandangan bahwa agama-agama lain yang ada di dunia ini sebagai yang mengandung kebenaran dan dapat memberikan manfaat serta keselamtan bagi penganutnya. Selain itu, iklusifitas dimaksudkan tidak semata-mata menunjukkan pada kenyataan tentang adanya kemajemukan, melainkan keterlibatan aktif terhadap kenyataan kemajemukan tersebut. $^{47}$

Secara filosofis-teoretis, paham inklusivisme dapat ditemukan dalam

${ }^{44}$ Peristiwa pengusiran umat Islam oleh kaum nasrani dari Spanyol ini dapat dibaca misalnya dalam Peter L. Berger, Pyramida Kurban Manusia, (Jakarta: LP3ES, 1983), h. 134

${ }^{45}$ Badri Yatim, Sejarah Peradaban Islam (Dirasah islamiyah II), (Jakarta: PT. Raja Grafindo Persada, 1994), h. 76-79

${ }^{46}$ Echols, Kamus Bahasa Inggris..., h. 316

${ }^{47}$ Alwi Shihab, Islam Inklusif, (Bandung: Mizan, 1998), h. 41 
kajian ilmu perbandingan agama. Dalam konteks ini, Huston Smith mengungkapkan bahwa salah satu agama saja sebenarnya sama dengan mengatakan bahwa Tuhan hanya ditemukan dalam ruangan ini saja dan tidak ada di ruangan sebelah atau hanya dalam busana ini saja, dan tidak ada dalam busana lain. ${ }^{48}$ Senada dengan Smith, Schuon juga mengatakan, dalam kenyataannya tidak ada bukti-bukti yang mendukung pernyataan bahwa kebenaran unik dan khusus hanya dimiliki agama tertentu saja. ${ }^{49}$

Paradigma inklusif membuka peluang bagi para santri untuk melakukan dialog antar agama-agama. Dialog ini tidak lebih dari sebuah pendidikan dalam pengertian yang paling luas dan paling mulia. Kendati demikain, ketika paham ini mau diterpkan, para santri selalu memperhatikan prasyaratnya yaitu komitmen yang kokoh terhadap agamanya masing-masng. Seorang santri inklusif, dalam berinteraksi dengan aneka ragam unsur masyarakat, tidak saja dituntut untuk membuka diri, belajar dan menghormati mitra dialognya, tetapi juga harus committed terhadap agama yang dianutnya. Hanya dengan sikap demikian, santri inklusif akan terhindar dari paham relativisme ${ }^{50}$

${ }^{48}$ Huston Smith, The Religion of Man, (terj.) Safroedin Bahar, Agama-agama Manusia, (Jakarta: Yayasan Obor Indonesia, 1985), h. 101

${ }^{49}$ Frithjof Schuon, The Transcendent Unity of Religion, (terj.) Safroedin Bahar, Mencari Titik Temu Agama-agama, (Jakarta: Pustaka Firdaus, 1987), h. 17

${ }^{50}$ Relativisme adalah pandangan tentang hal-hal yang menyangkut "kebenaran" atau "nilai" ditentukan oleh pandangan hidup serta kerangka berfikir seseorang atau masyarakatnya. Konsekwensi logisnya adalah doktrin agama apapun harus dinyatakan benar (semua agama sama). Karena itu, konsep atau paham ini tidak mengenal kebenaran absolut atau kebenaran abadi. dan sinkretisme. ${ }^{51}$

Di antara kaum santri yang memiliki paradigma keagamaan inklusif adalah Alwi Shihab dan Nurcholis Madjid. Bagi Cak Nur -panggilan akrab Nurcholis Madjid- agama itu harus diterima sebagai kelanjutan atau konsistensi hakikat kemanusiaan itu sendiri. Dengan kata lain, beragama yang benar harus merupakan kewajaran manusiawi. Cukuplah sebagai indikasi bahwa suatu agama atau kepercayaan tidak dapat dipertahankan jika ia memiliki ciri kuat bertentangan dengan naluri kemanusiaan yang suci. ${ }^{52}$ Karena itu, adanya perbedaan agama tidak mungkin dihindarkan, dan perbedaan tersebut harus disikapi dengan penuh kedewasaan di atas landasan jiwa persaudaraan, penuh pengertian, tenggang rasa dan kasih sayang.

Santri inklusif selalu menjunjung tinggi adanya paham keagamaan yang bersifat inklusif yang ditandai dengan adanya dialog dan kerja sama serta perasaan kemanusiaan. Bagi para santri penganut paradigma inklusif, cara keberagamaan seperti ini diyakini akan menimbulkan ketenteraman, keharmonisan, kedamaian dan ketahanan. Maka untuk mewujudkan hal itu perlu dilakukan kritik teks dan penafsiran para ulama atas teks-teks tersebut, serta

${ }^{51}$ Sinkretisme adalah menciptakan suatu agama baru dengan memadukan unsur-unsur tertentu atau sebagian komponen ajaran dari beberapa agama untuk dijadikan bagian integral dari agama baru tersebut. Lihat Nata, Peta Keragaman..., h. 190

${ }^{52} \mathrm{Hal}$ ini senada dengan firman Allah Swt dalam QS. Ar-Rûm [30]: 30. Ayat ini sesungguhnya menegaskan bahwa kecenderungan alami manusia kepada kebenaran (fitrah) merupakan agama yang benar dan kebanyakan manusia tidak menyadarinya. Lihat Nurcholis Madjid, Masyarakat Religius, (Jakarta: Paramadina, 1997), h. 47 
dengan menghilangkan unsur-unsur perbedaan dan mengedepankan unsurunsur persamaan. Selain itu, keberanian, ketulusan, kerelaan dan pandangan jauh ke depan adalah modal dasar bagi kaum santri untuk mewujudkan inklusivitas ini dalam dunia nyata.

\section{Rasionalis}

Kata rasional berasal dari bahasa Inggris, rational, yang berarti masuk akal, berakal. ${ }^{53}$ Kata rasional selanjutnya diartikan sebagai pikiran, pandangan dan pendapat yang sejalan dengan pendapat akal. Adapun pengertian akal adalah daya berfikir yang ada dalam diri manusia dan merupakan salah satu daya dari jiwa yang mengandung arti perfikir, memahami dan mengerti. ${ }^{54}$ Kata akal berasal dari bahasa Arab 'aqala ${ }^{55}$ yang berarti mengikat dan menahan. Pada zaman jahiliyah orang yang berakal ('âqil) adalah orang-orang yang dapat menahan amarahnaya dan mengendalikan hawa nafsunya, sehingga karenanya dapat mengambil sikap dan tindakan yang bijaksana dalam menghadapi segala persoalan. ${ }^{56}$

Dengan demikian, rasional adalah sesuatu yang masuk akal atau sesuatu yang sesuai dengan pendapat akal dengan berbagai tingkatannya. Rasional juga dapat berarti potensi rohaniah yang dapat mengajak manusia untuk membedakan antara yang benar dan salah, baik dan buruk. Paradigama

\footnotetext{
${ }^{53}$ Echols, Kamus Bahas Inggris..., h. 466

${ }^{54}$ Kafrawi Ridwan, dkk. (ed.), Ensiklopedi Islam, (Jakarta: Ichtiar Baru van Hoeve, 1999), h. 98

${ }^{55}$ Dalam Al-Qur'an, kata akal tidak disebutkan dalam bentuk masdar (al-'aql), namun dalam bentuk fi'il mudhâri' (kata kerja) sebanyak 49 kali dan tersbar di berbagai surat dalam Al-Qur'an. Lihat Muhammad Fuad Abdul Baqi, Mu'jam Mufahras li Alfâzh alQur'ân, (Bairut: Dar al-Fikr, 1981), h. 309

${ }^{56}$ Ridwan, Ensiklopedi..., h. 98
}

rasional berarti paradigma yang dalam menjelaskan ajaran-ajaran Islam tidak hanya mengandalkan wahyu, tetapi juga mengikutsertakan akal pikiran. Paradigma rasional juga berarti paradigma yang menghargai pendapat akal pikiran dan menggunakannya untuk memperkuat dalil-dalil ajaran agama.

Santri yang rasionalis memiliki ciriciri antara lain: 1) menggunakan akal pikiran dalam memperkuat argumen ajaran-ajaran agama yang dianutnya, tanpa meninggalkan wahyu; 2) Selalu mencari hikmah yang dapat diterima akal dari suatu ajaran agama; 3) Selalu berfikir sistematik, radikal dan universal; 4) Selalu bertanya dengan menggunakan pertanyaan mengapa; 5) Pemikirannya sejalan dengan hukumhukum Tuhan yang ada di alam; 6) Mencari penyesuaian antara pendapat akal dengan pendapat wahyu; 7) Hasil pemikiran akal dianggap bukan sesuatu yang final, melainkan hanya sementara. Karena itulah, bagi santri penganut paradigma rasionalis, pintu ijtihad tidak pernah tertutup. ${ }^{57}$

Sejatinya persoalan rasionalisme ini telah menjadi pembahasan yang hangat bagi para ulama di berbagai disiplin ilmu. Dalam bidang teologis misalnya, para teolog Islam telah membahas tentang kedudukan akal sebagai daya berfikir yang terdapat dalam diri manusia. Pembahasan mereka berkisar seputar apakah akal mampu mengetahui Tuhan, berterima kasih kepada Tuhan, mengetahui baik buruk serta kewajiban melakukan yang baik dan menjauhi yang buruk. ${ }^{58}$ Para ulama

\footnotetext{
${ }^{57}$ Nata, Peta Keberagaman..., h. 62-63

${ }^{58}$ Harun Nasution, Teologi Islam Aliran-aliran Sejarah Analisis Perbandingan, (Jakarta: UI Press, 1972), h. 93-94
} 
fikih dan ushul fikih juga kerap membahas persoalan akal terutama dalam konteks berijtihad, sehingga muncullah kelompok ahl ar-ra'y sebagai bandingan dari ahl al-hadîts. Dalam bidang filsafat juga dijumpai kelompok Islam rasionalis dalam rangka mencari hikmah atau kebenaran yang sejati dan berusaha menafsirkan pengalamanpengalaman manusia. ${ }^{59}$ Fenomena ini menunjukkan bahwa akal (rasionalitas) adalah tema yang cukup sentral dalam Islam.

Karena itu, tidak heran bila paradigma rasionalis ini tidak pernah sepi peminat. Di Indonesia sendiri, paradigma ini memiliki penggemar yang cukup banyak, bahkan di antara mereka banyak yang menjadi tokoh bangsa. Sekadar untuk menyebut nama misalnya adalah, Harun Nasution, Nurcholis Madjid, Abdurrhaman Wahid, Atho Muzdhar, Azyumardi Azra, dan Komarudin Hidayat. Mereka adalah tokoh-tokoh bangsa yang notabene pernah mengenyam pendidikan pesantren.

\section{TransformatiF}

Kata transformatif berasal dari bahasa Inggris, transformation, yang berarti perubahan (bentuk) atau menjadi. ${ }^{60}$ Dengan demikian, santri yang memiliki paradigma transformatif adalah santri yang mengubah, membentuk atau menjadikan. Yaitu mengubah keadaan masyarakat yang terbelakang menjadi masyarakat yang maju. Membentuk manusia yang biadab

${ }^{59}$ Umar Mohammad at-Toimy asy-Syaibani, Falsafah at-Tarbiyah al-Islâmiyah, (terj.) Hasan Langgulung, Filsafat Pendidikan Islam, (Jakarta: Bulan Bintang, 1979), h. 25

${ }^{60}$ Echols, Kamus Bahasa Inggris..., h. 601 menjadi manusia yang beradab. Atau membentuk dan menjadikan masyarakat sesuai dengan cita-cita Islam yaitu masyarakat yang mencapai kemajuan secara seimbang antara urusan dunia dan akherat, urusan iman dan amal, urusan material dan spiritual. ${ }^{61}$

Santri yang memiliki paradigma transformatif memiliki cirri-ciri antara lain: pertama, selalu berorientasi pada upaya mewujudkan cita-cita Islam yaitu membentuk dan mengubah keadaan masyarakat kepada cita-cita Islam; membawa rahmat bagi seluruh alam. Hal ini senada dengan firman Allah Swt dalam QS. Al-Anbiyâ' [21]: 107 dan QS. Al-An'âml [27]: 77).

Kedua, selalu menuntut adanya keseimbangan antara pelaksana aturanaturan yang formalistik dan simbolistik dengan misi ajaran Islam tersebut. Dengan kata lain, penganut paradigma ini mengupayakan keseimbangan antara pelaksanaan syari'at Islam yang bersifat simbolis dengan makna yang bersifat inti dan esensial. Pelaksanaan syari'at yang bersifat simbolis dapat menimbulkan kesalehan individual, sedangkan pelaksanaan makna yang bersifat esensial akan menumbukan kesalehan sosial. Ketiga, selalu berorientasi untuk mewujudkan citacita Islam, khususunya untuk mengangkat derajat kaum dhu'afa'; diarahkan untuk menyebarkan nilainilai kemanusiaan seperti kasih sayang, sopan santun, kejujuran, keikhlasan; menegakkan nilai-nilai demokratis seperti kesederajatan (egaliter), kesamaan kedudukan (equality) dan sebagainya. Dengan tegaknya nilai-nilai tersebut, maka nasib orang-orang yang

${ }^{61}$ Nata, Peta Keberagaman..., h. 78 
selama ini belum beruntung -terutama kaum fakir miskin dan dhu'afa'- akan terangkat.

Keempat, senantiasa memiliki concern dan respon terhadap berbagai masalah aktual yang terjadi dalam masyarakat. Hal ini sejalan dengan masa awal kedatangan Islam lima belas abad silam, dimana Islam datang untuk ikut serta memecahkan berbagai masalah yang terjadi dalam masyarakat, terutama masalah ketimpangan sosial, kemiskinan dan penindasan, dengan cara mencari akar permasalahannya, yakni dengan meluruskan sikap, pandangan hidup dan paham teologinya melalui ajaran keimanan dan akhlak serta pendidikan. Dalam konteks ini, jika dalam ajaran Islam terjadi halhal yang tidak sejalan dengan upaya pemecahkan berbagai masalah tersebut di atas, maka harus diluruskan, diperbaharui dan disesuaikan dengan semangat ajaran Al-Qur'an. Dengan cara demikian, maka santri transformatif identik dengan santri yang memiliki paradigma alternatif.

\section{Aktual}

Aktual berasal dari bahasa Inggris, actual, yang berarti keadaan sebenarnya, memang betul-betul dan sesungguhnya. ${ }^{62}$ Kata aktual dalam konteks ini dapat pula berarti sesuatu yang semula merupakan potensi, lalu potensi itu menampakkan dirinya dalam kenyataan sehingga menjadi identitas dan ciri-ciri dari sesuatu itu. Sebagai contoh, seseorang memiliki bakat menulis lalu bakat itu diekspresikan dalam kenyataan dengan cara menulis berbagai macam karya tulis, maka karya tulis tersebut

${ }^{62}$ Echols, Kamus Bahasa Inggris..., h. 94 dikatakan sebagai hasil dari aktualisasi potensi yang bersangkutan.

Secara potensial, Islam adalah agama yang sangat ideal, unggul dan lengkap dalam hal meletakkan dasardasar bagi pegangan hidup. Namun potensi ideal Islam itu dalam kenyataan aktualnya bisa saja sebaliknya. Islam aktual menghendaki agar apa yang terdapat dalam kitab suci tersebut menjadi kenyataan dalam kehidupan nyata. Dalam konteks ini, Jalaluddin Rahmat mengatakan bahwa Islam itu ada dua macam yaitu konseptual dan aktual. Islam konseptual terdapat dalam Al-Qur'an, Sunnah dan buku-buku atau ceramah-ceramah tentang keislaman, sementara Islam aktual terdapat pada prilaku pemeluknya. ${ }^{63}$

Dari penjelasan tersebut dapat diketahui bahwa santri yang berparadigma aktual memiliki cirri-ciri antara lain: pertama, santri aktual selalu menampakkan prilaku sesuai dengan ajaran Islam sebagai realisasi atau pengamalan dari ajaran Islam yang tertuang dalam Al-Qur'an dan Sunnah. Kedua, selalu berusaha agar ajaran Islam yang ada dalam Al-Qur'an dan Sunnah terlihat dalam kenyataan empirik dan prilaku.

Ketiga, karena sifatnya pengalaman, maka Islam aktual adalah Islam yang telah mempribadi. Karena itu dalam prosesnya, Islam aktual ini akan bersinggungan atau dipengaruhi oleh berbagai faktor di mana Islam itu dipraktekkan. Keempat, karena sifatnya yang telah mempribadi, maka kendatipun sumbernya satu namun Islam aktual akan menemukan bentuknya yang amat bervariasi dan

${ }^{63}$ Jalaluddin Rahmat, Islam Aktual, (bandung: Mizan, 1996), h. 18 
beragam. Kelima, bersifat sangat pribadi, dan karenanya sangat sulit sekali untuk dicarikan definisi tentang Islam yang dapat dipakai oleh seluruh umat manusia. Definisi yang dapat diterima seluruh umat adalah definisi yang terdapat dalam kitab suci Al-Qur'an.

Berdasarkan ciri-ciri di atas, tampak jelas bahwa paradigma aktual adalah paradigma yang dihayati dan dipraktekkan oleh penganutnya dalam kenyataan hidup sehari-hari di masyarakat. Tidak hanya itu, paradigama ini sudah menjadi semacam tradisi dan cara untuk memecahkan berbagai masalah sosial kemasyarakatan, ekonomi, politik dan lain sebagainya.

\section{KonservatiF}

Secara etimologis, konservatif adalah kolot, bersikap mempertahankan keadaan, kebiasaan, dan tradisi yang berlaku. ${ }^{64}$ Paradigma ini adalah paradigma yang cenderung bersifat konservatif, yang memposisikan Islam sebagai agama yang memiliki doktrin dan ikatan-ikatan tradisi lama yang belum mau bersentuhan dengan wacana keilmuan selain Islam. Unsurunsur sosial selain Islam dalam hal ini dianggap sebagai bagian yang senantiasa berlawanan bahkan mengancam. Dalam dimensi teologi, Tuhan menempati pokok segala kekuasaan yang telah diterjemahkan dalam kajian-kajian pendahulunya dengan peletakan unsur mazhab yang dianggap representatif. Tuhan dengan segala kekuasaannya telah memberikan ukuran dan solusinya sesuai dengan ajaran yang tertulis. Bagi mereka menafsirkan ayat yang berkaitan dengan ketuhanan dengan metode baru adalah kesesatan.

\footnotetext{
${ }^{64}$ Tim Penulis, Kamus Bahasa Indonesia..., h. 802
}

Demikian pula dalam bidang syariat yang menjadi pusat kajian hukumnya. Aspek hukum yang telah ada dalam kitab-kitab tersebut sudah menjadi final untuk dijadikan acuan hukumnya. Alasannya, hukum tersebut murni bersumber dari Al-Qur'an dan hadis. Oleh karenanya, tidak ada yang perlu disempurnakan lagi. Realitas sosial politik yang menandai kemunculan hukum-hukum tersebut nyaris tak mendapatkan tempat kajian yang mendalam.

Dalam kategori sosiologis Islam seperti di atas, menurut Ali Syariati (1933-1977), Islam hanya menjadi kumpulan-kumpulan dari tradisi asli dan kebiasaan masyarakat yang memperlihatkan suatu semangat kolektif suatu kelompoknya. ${ }^{65}$ Ia berisi kumpulan kepercayaan nenek moyang, perasaan individual, tata cara, ritual, aturan, kebiasaan, dan praktik-praktik dari suatu masyarakat yang telah mapan, berlangsung dari generasi ke generasi. Kebiasaan inilah yang biasanya dipelihara oleh penguasa politik untuk melegitimasi kekuasaan. Karena indoktrinasi menjadi bagian yang kuat dalam pemaknaan ajaran agama maka paradigma ini sering pula disebut paradigma konservatif.

Bagi santri yang berpaham konservatif ini, "ketidakberubahan" (unchangingness) merupakan suatu hal yang ideal bagi individu dan masyarakat serta merupakan suatu persepsi hakikat manusia dan lingkungannya. "Ketidakberubahan" merupakan asumsi berpengaruh luas yang mewarnai hampir seluruh aspek pemahaman

\footnotetext{
${ }^{65}$ Faiz Manshur, Pilihan Paradigma Islam...
} 
kelompok ini. ${ }^{66}$ Doktrin "ketidakberubahan", baik sebagai fakta maupun sebagai cita-cita, barangkali bermula dari pengalaman kehidupan nomadik bangsa Arab, yang mengakibatkan timbulnya paham bahwa keselamatan terletak pada upaya mengikuti jejak para leluhur. Bangsa nomad Arabia tentu saja menyadari perubahan. Suku-suku berhasil dan berkembang semakin meningkat, lalu mengalami nasib pahit, mundur dan terkadang lenyap sekaligus. Namun variasi perubahan seperti itu tidak berarti bahwa pada dasarnya kehidupan mengalami perubahan. Dengan demikian, lebih baik melakukan apa-apa yang telah dilakukan nenek moyang sebab dalam banyak hal, cara itu membuahkan hasil yang memuaskan. Iklim Arabia itu tidak menentu dan tak teratur sehingga orang nomad tidak dapat menghindari bencana dengan membuat rencanarencana cermat, tetapi terpaksa membiasakan diri menerima apa saja yang terjadi pada dirinya ${ }^{67}$ Corak berpikir seperti itu mengakibatkan doktrin mengikuti "jejak leluhur" menjadi opini paling kuat. Segala yang baru pasti akan dicurigai. Dalam teologi Islam, kata yang lazim dipakai untuk "hal baru" ialah bid'ah. Berlandaskan corak pemikiran tersebut akhirnya kelompok konservatif pun memandang bahwa globalisasi adalah unsur yang sangat mengancam bagi keberlangsungan nilai-nilai Islam.

Melihat pemahaman tersebut dapat dimengerti bahwa kelompok ini, sebagaimana telah dijabarkan di atas

66 William Montogomery Watt, Islamic Fundamentalist and Modernity, (terj.) Fundamentalis dan Modernitas dalam Islam, (Jakarta: CV. Pustaka Setia, 2003), Cet. I, h. 11-12

${ }^{67}$ Watt, Islamic Fundamentalist..., h. 15 cenderung memposisikan Islam sebagai agama yang serba lengkap, sehingga doktrin dan ikatan-ikatan tradisi lama yang ada tidak dapat bersentuhan dengan wacana keilmuan selain Islam. ${ }^{68}$

\section{LiBERAL}

Secara harfiah liberal berarti sifat yang condong kepada kebebasan, berpandangan bebas (luas dan terbuka). ${ }^{69}$ Paradigma liberal adalah paradigma yang bersifat antagonistik dengan paradigma konservatif. Islam diasumsikan sebagai agama yang dapat berperan sebagai agen perubahan sosial. Unsur-unsur sosial selain Islam dalam hal ini menjadi komponen yang diterima bahkan menjadi acuan penting di dalam merumuskan berbagai solusi terhadap persoalan kekinian yang dihadapi umat. Dalam dimensi teologi paradigma ini mengedepankan aspek rasionalisme. Teologi bukan semata menjadi objek kajian bagaimana meyakinkan umat secara doktriner, melainkan sebagai pembimbing tindakan praksis sosial. Selain itu, teologi juga harus lepas dari paradigma kekuasaan negara, bahkan harus menjadi bagian transformasi sosial yang terus menyuarakan kepentingan mayoritas umat. Paradigma ini berpendirian bahwa walaupun Islam memiliki doktrin dan ikatan-ikatan tradisi lama tapi harus dilakukan banyak dekonstruksi terhadap pemahaman doktrin tersebut melalui pengembangan wacana keilmuan yang dapat diperoleh pada sumber-sumber eksternal.

\footnotetext{
${ }^{68}$ Mardias, Islam Dan Tantangan Globalisasi: Berbagai Paradigma Islam Dalam Menghadapi Globalisasi, dimuat dalam http:// diaz2000.multiply.com pada tanggal 22 Februari 2007

${ }^{69}$ Tim Penulis, Kamus Bahasa Indonesia..., h. 924
} 
Berkebalikan dengan teologi kaum konservatif yang gigih membela Tuhan, dimensi teologi yang mereka ajukan justru menginginkan konsistensi menjelmakan nilai tauhid sebagai ajaran yang membebaskan umat dari penindasan kultural dan struktural. Mereka lebih menekankan pembelaan terhadap nilai-nilai kemanusiaan, sehingga terkadang melampaui garisgaris "larangan" •demi mewujudkan teologis humanisnya. Dalam dimensi syariat paradigma ini mengambil hukum-hukum melalui pemahaman yang cenderung terlalu kontekstual, sehingga terkadang mengabaikan tekstualitas dan latar belakang munculnya doktrin-doktrin agama. Mereka juga mengajukan berbagai wacana tentang perlunya tafsir ulang terhadap Al-Qur'an dan hadis. Paradigma pemikiran yang cenderung sangat liberal ini sering diistilahkan dengan paradigma liberal.

Secara ringkas, paradigma liberal ini sebenarnya berakar pada ide demokrasi. Pemikiran-pemikiran lain sebagai derivatnya akan terlihat sangat bertumpu di atas paham demokrasi ini; seperti gagasan pemisahan negara dengan agama, hak-hak wanita dalam kepemimpinan politik dan kekuasaan, kebebasan penafsiran teks-teks agama, kebebasan berpikir dan berpendapat, toleransi beragama, dialog dan keterbukaan antar agama, pluralisme, demokrasi religius, dan lain-lain. ${ }^{70}$

\section{Penutur}

Tidak dipungkiri bahwa dalam sejarah perjuangan umat Islam Indonesia, terutama pada masa perjuangan kemerdekaan, santri

\footnotetext{
${ }^{70}$ Mardias, Islam Dan Tantangan Globalisasi...
}

merupakan salah satu ujung tombak pergerakan melawan penjajah. Semangat mereka untuk mempertahankan tanah air dan hidup merdeka dari penjajahan sangat kuat. Pasca kemerdekaan, santri juga terus melakukan misi dan tugas agungnya; menyebarkan dan mendakwahkan risalah Islam. Dalam konteks ini, mereka menggunakan berbagai macam cara; ada yang terjun di dunia politik, dunia pendidikan, kebudayaan, ekonomi dan ada juga yang melakukannya dengan jalan "kekerasan" atau terror.

Berbagai macam usaha itu pada dasarnya adalah ekspresi personal yang menyeruak dari paradigma keberagamaan yang mereka miliki. Bagi santri yang berparadigma fundamentalis atau konservatif misalnya, ia akan cenderung menggunakan cara-cara "kekerasan" dalam aktivitas dakwahnya. Namun bagi santri yang berpardigma rasionalis dan transformatif barangkali akan cenderung melakukan dakwah dengan jalan yang santun dan persuasif. Berbagai macam paradigma itulah yang mempengaruhi cara berfikir dan prilaku santri. Munculnya keragaman paradigma ini berawal dari keragaman model pembelajaran di pesantren, bukubuku bacaan dan tingkat pemahaman santri terhadap wacana keagamaan serta kondisi lingkungan yang melingkupi pesantren tersebut.

Sebagai catatan akhir, penulis melihat bahwa walaupun paradigma keberagamaan santri sangat beragam, namun pada intinya semua aksi yang menyeruak dari dalam jiwa mereka merupakan refleksi dan ekspresi untuk menyebarkan risalah agama yang agung nan mulia. Kendatipun demikian, penulis juga tetap berkeyakinan bahwa paradigma 
keberagamaan kaum santri yang orisinil adalah paradigma yang pro kelenturan, kesantunan, dan keadaban Islam. Karena paradigama seperti itulah yang sejalan dengan ajaran Islam yang sesungguhnya. Dan paradigma seperti itu pulalah yang akan memberi kekuatan bagi kaum santri untuk terus berupaya menjadikan nilai-nilai Islam sebagai ajaran penebar kasih, cinta dan sayang, serta rahmat bagi semesta alam (rahmatan li al-'âlamîn).[]

\section{DAFTAR PUSTAKA}

Abdul Kholiq, Paradigma Spiritualitas dalam Tradisi Sinoman, Penelitian Tradisi Sinoman dalam Masyarakat di Desa Bermi, Demak (tidak diterbitkan).

Abdul Munir Mulkhan, Runtuhnya Mitos Politik Santri: Strategi Kebudayaan dalam Dakwah Islam, (Yogyakarta: Sipress, 2004)

Abu al-Husain Muslim bin al-Hajjaj bin Muslim bin Kausyaz al-Qusyairi an-Naisaburi, Shahih Muslim, (Bairut: Dâr Shadir, t.t.)

Abuddin Nata, Peta Keragaman Pemikiran Islam di Indonesia, (Jakarta: PT. Raja Grafindo Persada, 2001), h. 30

al-Wahidi, Asbâb an-Nuzûl, (Kairo: Dâr at-Tirats al-'Arabi, t.t.)

Alwi Shihab, Islam Inklusif, (Bandung: Mizan, 1998)

Badri Yatim, Sejarah Peradaban Islam (Dirasah islamiyah II), (Jakarta: PT. Raja Grafindo Persada, 1994)

Charles T. Tart, Transpersonal Psychologies, (New York: Happer \& Row, 1969)

Clifford Geertz, Abangan, Santri, Priyayi Dalam Masyarakat Jawa, (Jakarta: Pustaka Jaya, 1983)

Clifford Geertz, The Religion of Java, Fazlur Rahman, Islam (terj.) Senoaji
(Chicago: The University of Chocago Press, 1976)

Dani Vardiansyah, Filsafat Ilmu Komunikasi: Suatu Pengantar, (Jakarta: Indeks, 2008)

Dawam Raharjo, "Fundamentalisme" dalam Muhammad Wahyuni Nafis (ed.), Rekonstruksi dan Renungan Religius Islam, (Jakarta: Paramadina, 1996)

Departemen Agama RI, Pondok Pesantren dan Madrasah Diniyah, Pertumbuhan dan Perkembangannya, (Jakarta: Ditjen Kelembagaan Agama Islam Departemen Agama RI, 2003)

Direktorat Pembinaan Perguruan Tinggi Agama Islam Direktorat Jenderal Pembinaan Kelembagaan Agama Islam Departemen Agama RI, Buku Teks Pendidikan Agama Islam Pada Perguruan Tinggi Umum, (Jakarta: PT. Bulan Bintang, t.t.), Cet. I

Douglas A. Bernstein, Essentials of Psychology, (New York: Houghton Mifflin, 1999)

Faiz Manshur, Pilihan Paradigma Islam Menghadapi Globalisasi, http:// www.pikiran-rakyat.com/cetak/ 0303/21/0801.htm 
Saleh, (Jakarta: Bina Aksara, 1987)

Frithjof Schuon, The Transcendent Unity of Religion, (terj.) Safroedin Bahar, Mencari Titik Temu Agama-agama, (Jakarta: Pustaka Firdaus, 1987)

George Ritzer, Encyclopedia of Social Theory, (SAGE Publications, Inc, 2004)

Harun Nasution, Islam Ditinjau Dari Berbagai Aspek Jilid I, (Jakarta: UI Press, 1985), Cet. V

Harun Nasution, Teologi Islam Aliranaliran Sejarah Analisis Perbandingan, (Jakarta: UI Press, 1972)

Hasbullah, Kapita Selekta Pendidikan Islam, (Jakarta: PT. Raja Grafindo Persada, 1999)

Hiroko Horikoshi, Kyai dan Perubahan Sosial, (Jakarta: P3M, 1987)

Huston Smith, The Religion of Man, (terj.) Safroedin Bahar, Agama-agama Manusia, (Jakarta: Yayasan Obor Indonesia, 1985)

Jalaluddin Rahmat, Islam Aktual, (bandung: Mizan, 1996)

John L. Eposito, The Oxford Encyclopedia of The Modern Islamic, (World, New York, 1995)

John M. Echols dan Hasan Shadily, Kamus Bahasa Inggris-Indonesia, (Jakarta: PT. Gramedia, 1979), Cet. VII

Kafrawi Ridwan, dkk. (ed.), Ensiklopedi Islam, (Jakarta: Ichtiar Baru van Hoeve, 1999)

Kuntowijoyo, Identitas Politik Umat Islam, (Bandung: Mizan, 1997)

M. Amin Abdullah, Studi Agama Normativitas atau Historisitas?,
(Yogyakarta: Pustaka Pelajar, 1996)

M.'Âbid al-Jâbirî, Dharûrah al-Bahts 'an Niqath al-Iltiqâ li Muwâjahah alMashîr al-Musytarak, dalam Hassan Hanafi \& M. 'Âbid AlJâbirî, Hiwâr al-Masyriq wa alMaghrib, (Bairut: Muassasah alArabiyyah, 1990)

Mannâ' al-Qhatthan, Mabahits fî̀ 'Ulûm al-Qur'ân, (Mansyurat al-'Ashr alHadits, t.t.)

Mark R. Woodward, Islam Jawa: Kesalehan Normatif versus Kebatinan, (Yogyakarta: LkiS, 1999)

Mohamad S. Iman, Paradigma Terorisme, dimuat di harian Republika pada 5 September 2003.

Muhammad Fuad Abdul Baqi, Mu'jam Mufahras, (Bairut: Dâr al-Fikr, 1981)

Nurcholis Madjid, Masyarakat Religius, (Jakarta: Paramadina, 1997)

Peter L. Berger, Pyramida Kurban Manusia, (Jakarta: LP3ES, 1983)

Subhi Shalih, Membahasa Ilmu-Ilmu AlQur'an (terj.), (Jakarta: Pustaka Firdaus, 1991)

Syamsul Arifin, dkk., Spiritualisasi Islam dan Peradaban Masa Depan, (Yogyakarta: SIPRESS, 1996)

Tim Penulis, Kamus Bahasa Indonesia, (Pusat Bahasa Depdikbud RI, 2008)

Umar Mohammad at-Toimy asySyaibani, Falsafah at-Tarbiyah alIslâmiyah, (terj.) Hasan Langgulung, Filsafat Pendidikan Islam, (Jakarta: Bulan Bintang, 1979) 
W.J.S Poerwadarminta, Kamus Umum Bahasa Indonesia, (Jakarta: Balai Pustaka, 1991), Cet. XII

William Montogomery Watt, Islamic Fundamentalist and Modernity, (terj.) Fundamentalis dan Modernitas dalam Islam, (Jakarta: CV. Pustaka Setia, 2003), Cet. I

Yusril Ihza Mahendra, "Fundamentalisme, Faktor dan Masa Depannya," dalam Muhammad Wahyuni Nafis (ed.), Rekonstruksi dan Renungan Religius Islam, (Jakarta: Paramadina, 1996)

Zamakhsyari Dhofier, Tradisi Pesantren: Studi Tentang Pandangan Hidup Kyai, (Jakarta: LP3ES, 1994)

Zamroni, Pengantar Pengembangan Teori Sosial, (Yogyakarta: Tiara Wacana Yogya, 1992)

\section{Internet:}

Ach. Ma'ruf, Beredel Paradigma KritisTransformatif, dimuat dalam http:/ /pmiingalah.wordpress.com pada tanggal 7 Februari 2009

Anjrah Lelono Broto, Fundamental dan Liberal dalam Islam, dimuat dalam blog www.anantapunya.com pada 5 September 2009

Mardias, Islam Dan Tantangan Globalisasi: Berbagai Paradigma Islam Dalam Menghadapi Globalisasi, dimuat dalam http:// diaz2000.multiply.com pada tanggal 22 Februari 2007

Syamsul Arifin, Belajar dari Pondok $P \quad e \quad s \quad a \quad n \quad t \quad r \quad e \quad n$, www.coelzlamboe.blogspot.com, 31 Mei 2009

64 Dialog No. 68, Tahun XXXII, Nopember 2009 